\title{
Does Reducing College Costs Improve Educational Outcomes for Undocumented Immigrants? \\ Evidence from State Laws Permitting Undocumented Immigrants to Pay In-state Tuition at State Colleges and Universities*
}

\author{
Aimee Chin \\ Chinhui Juhn
}

\begin{abstract}
Ten states, beginning with Texas and California in 2001, have passed laws permitting undocumented students to pay the in-state tuition rate - rather than the more expensive out-ofstate tuition rate - at public universities and colleges. We exploit state-time variation in the passage of the laws to evaluate the effects of these laws on the educational outcomes of Hispanic childhood immigrants who are not U.S. citizens. Specifically, through the use of individual-level data from the 2001-2005 American Community Surveys supplemented by the 2000 U.S. Census, we estimate the effect of the laws on the probability of attending college for 18- to 24-year-olds who have a high school degree and the probability of dropping out of high school for 16- to 17year-olds. We find some evidence suggestive of a positive effect of the laws on the college attendance of older Mexican men, although estimated effects of the laws in general are not significantly different from zero. We discuss various reasons for the estimated zero effects. Two important considerations are that little time has elapsed since the state laws were passed and that unchanged federal policy on financial aid and legalization for undocumented students may dampen the state laws' benefits. Thus, the longer-run effects of the laws may well differ from the short-run effects presented in this paper.
\end{abstract}

\footnotetext{
* Chin: Associate Professor, Department of Economics, University of Houston, 204 McElhinney Hall, Houston, TX 77204-5019 (email: achin@uh.edu); Juhn: Henry Graham Professor of Economics, Department of Economics, University of Houston, 204 McElhinney Hall, Houston, TX 77204-5019 (email: cjuhn@uh.edu). We thank Peter Mieszkowski, Stephen Trejo and participants in the IUPLR Conference in April 2007 for helpful comments and discussion. We also thank Aly Capetillo, Serguei Chervachidze and Parul Mathur for research assistance. Financial support from Rice University's Baker Institute for Public Policy is gratefully acknowledged. The authors bear sole responsibility for the content of this paper.
} 


\section{Introduction}

State colleges and universities typically charge a much lower tuition to students who have established residency in the state than to students who reside elsewhere. Debate has ensued over how to treat undocumented immigrants who arrived in the United States as children. They may have grown up in the state, but because they are in the United States without legal authorization, it is not clear whether they have met the residency requirements for in-state tuition. State governments define residency requirements, and thereby have the ability to determine whether an undocumented student who has been living in that state qualifies for in-state tuition. Ten states, beginning with Texas and California in 2001, have passed laws permitting undocumented students to enroll in public universities and colleges as state residents. In this paper, we evaluate the impact of such laws on the educational outcomes of undocumented immigrants.

An evaluation of these laws is of interest for a number of reasons. First, additional states are considering passing similar laws. Evidence for whether these laws help intended beneficiaries would assist states in deciding whether to adopt them. Second, the lower educational attainment of Hispanic immigrants and their children relative to non-Hispanics have been a major domestic policy concern. Undocumented immigrants are predominantly from Mexico and Central America and make up a disproportionate share of less-educated Hispanics. ${ }^{1}$ It would be useful to understand the extent to which the high price of college education is responsible for the poor educational outcomes of undocumented immigrants. Access to affordable college education may induce high school graduates to go on to college, and perhaps even induce children who would have dropped out of high school (because there was no hope of attending college) not to drop out. Might reducing the price of college education increase

\footnotetext{
${ }^{1}$ Smith (2006), Table 2 reports that while average years of schooling was 12.99 for all U.S.-born in 1996, it was 12.64 for legal immigrants, and 10.79 for illegal immigrants. For Hispanics, years of schooling was 11.52 for the U.S.-born, 10.12 for legal immigrants, and 6.90 for illegal immigrants.
} 
educational attainment for undocumented immigrants?

We exploit state-time variation in the passage of the laws permitting undocumented immigrants to pay in-state tuition to evaluate the effects of these laws. Specifically, we are not comparing outcomes in a particular state before and after the law is passed to determine the effect of the law, nor are we comparing outcomes in states that have the law to states that do not have the law. Instead, we are using a difference-in-differences-type identification strategy in which the change in outcome over time for states that passed the law earlier are compared to the change over time for states that passed the law later or that have not passed it; that is, the identifying assumption is that without the law, changes in outcome would have been the same between earlier passers and later/never passers. ${ }^{2}$ We explore the validity of this assumption by examining U.S.-born Hispanics - they are legal U.S. residents but arguably experience similar conditions in terms of obstacles to higher education in the state.

We apply our identification strategy to individual-level data from the 2001-2005 American Community Surveys supplemented by the 2000 U.S. Census. To preview the results, although we find some evidence suggestive of a positive effect of the laws on the college attendance of Mexican men, estimated effects of the laws in general are not significantly different from zero. We discuss various reasons for the estimated zero effects. Two important considerations are that little time has elapsed since the state laws were passed and that unchanged federal policy on financial aid and legalization for undocumented students may dampen the state laws' benefits. Thus, the longer-run effects of the laws may well differ from the short-run effects presented in this paper.

This paper is organized as follows. In the next section, we provide a brief background on

\footnotetext{
${ }^{2}$ In other words, we will always have state-fixed effects and time-fixed effects in the estimated regressions. Details are provided in the Related Literature section.
} 
these laws permitting undocumented students to pay in-state tuition and discuss related literature. Following that, we propose a theoretical and empirical framework. We then discuss the data and present our results. We discuss the findings in the last section.

\section{Background}

\section{A. Legislative Background}

The rise in the number of undocumented immigrants has been an impetus for state laws permitting them to pay in-state tuition at public colleges or universities. In 2004, there were an estimated 10.3 million undocumented immigrants in the United States, which constitute 29 percent of the foreign-born population in the country (Passel 2005). Undocumented immigration has grown dramatically in recent decades, such that undocumented immigrants represent a larger share of recent immigrants than immigrants who have lived in the United States a long time. For example, in 1995, nearly half (an estimated 45 percent) of recent immigrants were undocumented, in contrast to 28 percent in 1980 and 5 percent in 1970 (Smith 2006, Table 4, which uses data from Passel). Many of the undocumented immigrants were born in Mexico and other countries in Latin America. In 2004, 57 percent of undocumented immigrants were born in Mexico and 24 percent were born in the rest of Latin America (Passel 2005).

Among these undocumented immigrants are foreign-born children who followed their parents to the United States; in 2004, 14 percent of all undocumented immigrants were undocumented children (Passel 2005). U.S. law requires education through grade 12 to be provided irrespective of legal status, thus providing full access to public schools up through grade 12 to these undocumented children. ${ }^{3}$ Proponents of the laws permitting undocumented students to pay in-state tuition argue that undocumented children who grew up in the state should

\footnotetext{
${ }^{3}$ As required by the Plyler v. Doe Supreme Court decision in 1982 and subsequent laws.
} 
continue to have the same access to the state's educational institutions as their legally resident classmates even after high school. An important premise is that the undocumented children should not be penalized for their parents illegally entering and/or staying in the United States; if their undocumented children have performed well in school, they should be rewarded with the same opportunity to attend college as their legally resident classmates.

California and Texas are the two states with the most undocumented immigrants California has 24 percent of the nation's unauthorized immigrants and Texas has 14 percent and were the first two states to adopt these laws permitting undocumented immigrants to pay instate tuition. Between 2002 and 2006, eight more states passed these laws (see Table 1), some with a substantial number of undocumented immigrants (e.g., New York with 7 percent of the total unauthorized population and Illinois with 4 percent) and others with relatively few (e.g., Nebraska with under 0.5 percent). Typically, out-of-state tuition is over twice the amount of instate tuition. In the 10 states that passed the law, the differential between in-state and out-of-state tuition amounted to a saving of $\$ 3,326$ per year per student in 2003 (U.S. Department of Education, NCES 2003).

Since the intended beneficiaries are undocumented immigrants who were brought over to the United States by their parents and who grew up in the state, only a limited subset of undocumented immigrants qualify for the in-state tuition. In general, to qualify, the prospective student must have: 1) attended a high school in the state for a certain number of years (typically, two to four years); 2) graduated from high school or completed a GED in the state; and 3) signed an affidavit stating that they intend to legalize their status as soon as they become eligible.

As of August 2006, 28 states had considered legislation allowing undocumented 
immigrants to pay in-state tuition (Krueger 2006). ${ }^{4}$ The federal government itself has been considering legislation that makes it easier for states to adopt such legislation, and to make it more worthwhile for undocumented students to take advantage of such legislation. The Dream Act, introduced in Congress in 2001, would provide a route to legal permanent residency status for undocumented students ${ }^{5}$ and remove penalties on states that allow undocumented students to pay in-state tuition. ${ }^{6}$ Understanding the effects of laws allowing undocumented immigrant students to pay in-state tuition would help states and Congress in their decision-making process.

\section{B. Related Literature}

We are not aware of published studies that use rigorous methods to study the effect of the laws permitting undocumented immigrants to pay in-state tuition on their educational outcomes, probably because most laws have only recently passed. ${ }^{7}$ Indeed, the $2006-07$ school year is only the sixth school year in which the law has been in effect for the earliest implementer (Texas), and fewer than four school years have elapsed for six of the 10 states. There may not yet be measurable outcomes in terms of completing a college degree, years of educational attainment, and labor market outcomes. Moreover, it may take time for undocumented immigrants to find out about the laws or for them to adjust their behavior in K-12 to put themselves in a position for college. Therefore, the effects may not be immediate.

Although there are currently no academic studies evaluating these laws, a story by Lewis

\footnotetext{
${ }^{4}$ Alaska and Virginia have considered legislation explicitly preventing undocumented students from paying in-state tuition, and are not counted among the 28.

${ }^{5}$ In particular, the law pertains to undocumented immigrants who have been in the United States at least five years, arrived at age 15 or younger, and graduates from high school would be granted six years of legal residence. At the end of the six years, if the undocumented immigrant has completed a two-year degree, completed at least two years of a four-year degree or served at least two years in the U.S. military, he/she will be granted permanent residence. ${ }^{6}$ The 1996 Illegal Immigration Reform and Immigrant Responsibility Act does not permit states to provide benefits in postsecondary education to undocumented immigrants that are not available to U.S. citizens. The Dream Act would remove any federal constraints on a state's ability to define "resident" for the purpose of receiving in-state tuition.

${ }^{7}$ Since the working paper version of this chapter was issued in January 2007 by Rice University's Baker Institute for Public Policy, we have become aware of Kaushal (2008), which evaluates these laws using Current Population Survey data.
} 
(2005) in the Boston Globe attempts to examine the enrollment effects. In Texas, enrollment of undocumented students increased from 1,500 in Fall $2001^{8}$ to 8,000 in Fall 2006. In California's University of California system - the state's most selective tier of higher education institutions 357 undocumented students were enrolled in the 2004-05 school year, which is the third school year with the law. Data were also provided for the University of New Mexico system, University of Utah system, University of Washington system, and all public institutions in Kansas, which revealed few undocumented students. The story's conclusion is revealed in the title: "In-state tuition is not a draw for many immigrants."

Our study is also interested in the effect of the laws on college enrollment, but we will examine enrollment in all higher education institutions rather than restricting the focus to state flagship systems (as undocumented immigrants for various reasons may be unlikely to attend a flagship institution) and also control for secular changes over time in the enrollment that have nothing to do with the laws. Moreover, we will consider the possibility that the law might have dynamic effects, such as raising high school graduation rates first, because now there is the prospect of attending college in the future.

There are also studies estimating the fiscal impact of these laws (Martin 2005; Institute of Public and International Affairs 2006). These studies examine the impact of the law on tuition revenue, with downward pressure coming from charging undocumented students the in-state tuition rate instead of the out-of-state tuition rate and an upward pressure coming from the entry of students who would otherwise not have attended a public college. In this study, we ignore the cost side and focus on the first-order question of whether the law raises educational attainment for undocumented students. If the law does not provide benefits to the intended beneficiaries, it

\footnotetext{
${ }^{8}$ Fall 2001 is the first semester in which the law was in effect in any state; the law was passed on June 16, 2001, which is too late to affect the application process and decision about which institution to attend for high school graduates wanting to attend a competitive public institution.
} 
should be eliminated because its cost - whatever the exact level is - is non-zero. ${ }^{9}$

Besides being (among) the first to estimate the effect of these laws on the educational outcomes of undocumented immigrants, this study adds to the more general literature on the effect of college costs on educational outcomes. Although this is a large literature, few studies have rigorously addressed the problem of endogeneity of college cost in estimating the effect of college cost on educational outcomes. ${ }^{10}$ Moreover, none of the studies that do address the problem of endogeneity have focused on the behavior of the children of immigrants. Among children under age 18 in the United States, 13.5 million (or 18.7 percent) are either immigrants themselves or have at least one parent who is an immigrant based on 2002 data (Capps, Fix and Reardon-Anderson 2003). The upsurge in immigration in recent decades means that children of immigrants will be a growing share of the U.S. population into the foreseeable future. It is therefore an urgent policy problem that the children of immigrants lag behind the children of natives in economic and educational achievement. These concerns are especially acute for immigrants from Latin America. Hispanic immigrants and their descendents do not converge to native levels of education as quickly as non-Hispanic immigrants and their descendents (see, for example, Card, DiNardo and Estes 2000; Grogger and Trejo 2002; and Smith 2003). The impact of college costs on the children of immigrants may not necessarily be the same as the impact on other subpopulations, and this paper goes part of the way toward filling the gap by examining the

\footnotetext{
${ }^{9}$ Technically, tuition revenue could increase overall with the law since the law could cause the enrollment of undocumented students to increase in a way that more than offsets the reduced revenue on a per-undocumentedstudent basis. However, it seems inaccurate to characterize the costs associated with the law as negative since there are marginal costs associated with increased enrollment, like a decrease in school inputs (e.g., faculty, facilities) on a per-student basis and spending on more school inputs.

${ }^{10}$ Some reasons for endogeneity are as follows. For example, financial aid awarded based on need may provide downward bias on aid's benefits because the estimated effect of aid will conflate the true effect of the aid and the effects of coming from a low-income family. Conversely, financial aid awarded based on merit may bias upwards the effect of aid on educational outcomes because the estimated effect also encapsulates the effect of the student attributes that earned him or her a merit-based award in the first place. Furthermore, comparing educational outcomes in states with lower and higher costs of attending public colleges and universities might be biased due to other differences between states that affect public tuition, such as in quality of education or returns to education.
} 
impact on undocumented immigrants.

The few studies that do treat the endogeneity of college costs convincingly are as follows. Kane (1994), using within-state changes in tuition at public institutions, finds that a $\$ 1,000$ decrease in tuition at public institutions raises college attendance by 3.7 percent. Dynarksi (2003), using a natural experiment involving the elimination of the Social Security student benefit program, finds that a $\$ 1,000$ increase in grant aid increases the probability of attending college by 3.6 percentage points and the years of completed schooling by 0.16 years. Dynarksi (2000), using a natural experiment involving the introduction of a large-scale merit aid program in Georgia, finds that a $\$ 1,000$ increase in aid raises the college attendance rate by 3.7-4.2 percentage rates. Dynarski (2005) finds that the large-scale merit aid programs in Arkansas and Georgia increased not only college attendance but also college completion. The effect is larger for women than men, and especially large for Hispanic and non-white women; Dynarski attributes this to the fact that girls outperform boys in high school, with the female advantage even starker among Hispanics and non-whites.

Although the four studies just described use distinct identification strategies, they reach a similar conclusion: college attendance and years of college education completed are highly sensitive to costs. However, studies of the Pell Grant program suggest smaller and close to zero effects on college attendance (Hansen 1983; Kane 1995; Seftor and Turner 2002). Arguably, the typical undocumented student may resemble a Pell Grant beneficiary - most of the $\$ 13$ billion in Pell Grants given annually are to students from families with income under $\$ 40,000$; perhaps we should not expect the laws to have any impact on educational outcomes. On the other hand, Dynarski (2005) did find that Hispanic and non-white women experienced the largest gains in college attendance and degree completion among all race/ethnicity-gender groups as a result of 
the Arkansas and Georgia merit aid programs - these programs would have been targeting lowand middle-income families during the time the affected cohorts considered in Dynarski (2005) would have been applying to college; perhaps it is not unreasonable to expect laws permitting undocumented students to pay in-state tuition to improve educational outcomes.

\section{Theoretical and Empirical Framework}

\section{A. Theoretical Considerations}

The laws allowing undocumented immigrants to pay in-state tuition effectively lower the price of attending college. Instead of paying the out-of-state price, undocumented immigrants meeting the criteria pay the in-state price, which, as we noted above, is an average annual savings of $\$ 3,326$. In the framework of an individual deciding whether to invest in a college education (perhaps together with his or her parents), since the cost of college education has decreased, we can expect demand for education to rise. This is because the reduction in price causes some people who did not "value" college education at the out-of-state tuition rate to now buy a college education. Moreover, given that the cost of attending four-year institutions far exceeds the cost of attending two-year institutions, the reduction in price might also cause people who would have stopped with a two-year degree to pursue a four-year degree. ${ }^{11}$ These people would have valued college education at least as much as the out-of-state two-year college price but less than the out-of-state four-year college price. The average in-state price at four-year colleges is lower than the average out-of-state price at two-year colleges, so these associate's degree holders will now enroll at the four-year institution for additional schooling, such as for a bachelor's degree.

\footnotetext{
${ }^{11}$ In 2003, public four-year institutions in the United States had average in-state tuition of $\$ 4,507$ and out-of-state tuition of $\$ 11,125$ (U.S. Department of Education, NCES 2003). In contrast, public two-year institutions had average in-state tuition of $\$ 2,217$ and out-of-state tuition of $\$ 5,076$ (ibid).
} 
It should be pointed out that a college education may still be prohibitively expensive for most undocumented immigrants even after the passage of the laws. Most undocumented children are from low-income families. Federal financial aid, which consists of grants (Pell Grants and Supplemental Educational Opportunity Grants), loans (Stafford and Perkins loans), and workstudy programs, is the main source of help for students from low-income families, but it is only available to U.S. citizens, U.S. nationals, and "eligible non-citizens." The latter category does not include undocumented immigrants, and it is comprised primarily of permanent residents. The reduction in price of a college education may be insufficient to draw some undocumented children away from the corner solution (for the poorest, the corner is no college education; for the less poor, the corner might be completing an associate's degree only).

The reason for the corner solution does not have to involve low valuation placed on a college education, but could just be the result of credit constraints. Relaxing credit constraints could lead not only to more years of college education, but also to a different composition of years of college education. In particular, it may cause undocumented immigrants to consume more education at four-year institutions. The reasons stem from the fact that attending four-year institutions is much more expensive than attending two-year institutions. In 2003, in the states that passed the law, the average out-of-state price of a year of college was $\$ 9,767$ for four-year public institutions and $\$ 4,365$ for two-year public institutions. The laws enable undocumented students to pay the in-state price of $\$ 3,620$ for four-year public institutions and $\$ 2,099$ for twoyear public institutions on average. Thus, as mentioned earlier in this subsection, some students who previously would have only attended two-year institutions will now continue their education at a four-year institution (thus, fraction of years spent at a four-year institution rises from nil to at least 50 percent if a BA is completed). 
Additionally, some students may substitute completely away from two-year colleges toward four-year colleges (fraction of years spent at a four-year institution rises from nil to 100 percent). These students value the higher quality of education at four-year colleges, such as higher quality faculty, greater course diversity, and additional student services, but due to credit constraints are only able to pay as much as the out-of-state tuition rate at two-year colleges. The average in-state price at four-year colleges is lower than the average out-of-state price at twoyear colleges, so now students can afford the higher-quality good. Thus, it is possible that even if we do not observe an increase in years of college education completed, there may be a change in composition of these college years toward higher quality; this compositional change would still be beneficial for the student and society.

There might be substitution not only away from two-year institutions toward four-year institutions, but also away from private colleges toward public colleges. Attending a private fouryear institution is more expensive than attending a public four-year institution, but after the law, the relative price is even higher. In 2003, the average tuition and fees at a private four-year institution is 1.37 times higher than at a public four-year institution at out-of-state prices but 3.38 times higher at in-state prices. There might exist some people who would choose a private college before the law who now choose a public college; though they value education at the private institution, they do not value it enough to pay more than triple the price.

The laws could have dynamic effects as well. If one plans on attending college, then one might take a more rigorous set of classes and apply more effort in high school and perhaps even in earlier grade levels. On the other hand, if one does not anticipate attending college, one might apply less effort at school and possibly even not bother completing high school. This suggests that the laws may not necessarily raise college enrollment immediately among undocumented 
students, because the first cohorts to be of college-going age while the law is in effect may have inadequate preparation for college and therefore not be in a position to take advantage of the law. For example, it might be too late for a high school junior to adjust her behavior so that she can have the coursework and grades to get into a competitive four-year college. By contrast, later cohorts would have time to make adjustments to place themselves in the position of applying for college in the senior year of high school. In summary, given the fact that ability to be get into college and perform well in college depends on past schooling investments, it could be that the law has no impact on cohorts who were juniors in high school or older at the time the law passed. Also, it could be that the law, by increasing student expectations of attending college, raises high school completion rates for younger cohorts.

Besides reducing the cost of attending a public post-secondary institution, the laws may have other effects that in turn affect schooling decisions. One such possibility is that the laws change perceptions about the future return to education. The Immigration Reform and Control Act (IRCA) of 1986 made it illegal for employers to knowingly hire an undocumented worker, and penalties include fines and prison time. The laws allowing undocumented students to pay instate tuition make post-secondary education cheaper, but do not change the legal status of undocumented students. Only the federal government can make legislation dealing with immigration in this respect, and currently Congress is considering the Dream Act, which provides a mechanism through which undocumented students (as well as those who serve in the armed forces) can become U.S. permanent residents. With legal status, undocumented immigrants would be able to apply to a much wider set of jobs and would not be restricted to the fringe economy that is less visible to IRCA enforcers.

This means that if undocumented immigrants want a college degree only for an increase 
in future earnings, the laws allowing undocumented students to pay in-state tuition may have negligible effects on college enrollment and completion. This is because even with a college degree, undocumented students would still be unable to get good jobs at U.S. firms. For example, a Wall Street Journal article by Jordan (2005) reports on the experience of the first graduating class to benefit from the Texas law, summarizing: "They are educated, but unable to get work because of their immigration status." On the other hand, it is possible that legislation allowing undocumented students to pay in-state tuition makes undocumented immigrants in that state more optimistic about the passage of the Dream Act. ${ }^{12}$ These more optimistic undocumented immigrants will have higher expectations of their return to education - since they believe they will gain legal status and therefore get better jobs - relative to undocumented immigrants in other states. There is good empirical evidence that legalization raises a worker's wages, and much of the wage gain comes from increases in returns to human capital (Kossoudji and CobbClark 2002) ${ }^{13}$ Since undocumented immigrants in states with the laws have higher expectations for legalization, their educational outcomes should improve relative to undocumented immigrants in other states. This legalization-based story might increase enrollment even in educational institutions whose prices for undocumented students are not affected by the laws, such as private colleges.

To summarize this subsection on theoretical considerations, the laws allowing undocumented immigrants to pay in-state tuition should increase (or eventually increase) college

\footnotetext{
${ }^{12}$ Alternatively, undocumented immigrants in states with the law may be more aware of the Dream Act itself (because information about it is found in the same place that information about the laws is provided), whereas those in other states do not know about the Dream Act. In this case, the former has higher expectations that legal status will be granted in the future than the latter.

${ }^{13}$ This study uses individual-level panel data to deal with the problem faced by other studies of the effect of legal status on wages that individual characteristics differ between legal and illegal immigrants. The variation in legal status is driven by IRCA, which provided amnesty to undocumented immigrants arriving to the U.S. before January 1,1982 . The authors deal with secular changes in wages over time by using a comparison group not experiencing any change in legal status.
} 
enrollment. Additionally, they may change the composition of post-secondary education (twoyear/four-year, public/private). The primary stories for these effects are the reduction in the price of college and the increase in expectations about the return to education for undocumented immigrants in states with these laws.

\section{B. Empirical Framework}

We wish to estimate the effect of the laws permitting undocumented immigrants to pay in-state tuition on the educational outcomes of undocumented immigrants. Our main identification strategy relies on the state-time variation in adopting the law. The law has been in effect since the Fall of 2001 semester in Texas, and the latest date of implementation is the Fall of 2006 in Nebraska, the 10th (and most recent) state to pass such a law. On the other hand, there are numerous states that have never had the law, although some are considering it. We can use states that passed the law later or never as controls for secular changes over time in outcomes for states that passed it earlier. To fix ideas, consider estimating the following regression model using repeated cross sections on young adults who are likely to be undocumented immigrants:

(1) $\mathrm{y}_{\text {ist }}=\alpha+\beta$ INSTATE $_{\mathrm{st}}+\delta_{\mathrm{s}}+\gamma_{\mathrm{t}}+\mathbf{x}_{\text {ist }} \rho+\varepsilon_{\text {ist }}$

For individual $i$ born in state $s$ observed at time $t, y_{i s t}$ is the outcome (e.g., college attendance), INSTATE $_{s t}$ is a binary variable indicating whether state $s$ has a law permitting undocumented immigrants to pay in-state tuition at time $t, \delta_{s}$ is state fixed effects, $\gamma_{t}$ is time fixed effects, and $\boldsymbol{x}_{i s t}$ is a vector of exogenous explanatory variables (e.g., age and sex of individual, time-varying state attributes).

This is a difference-in-differences-type identification strategy. In order to interpret the 
OLS estimate of $\beta$ in Equation 1 as the effect of the laws, we must assume that without the laws, the outcomes would have changed over time by same amount in the states that passed the laws earlier and the other states (this is known as the parallel trend assumption). It is not possible to directly test this identifying assumption; however, there are ways we might try to assess its validity. In this study, we will use legal residents to assess the validity of the parallel trend assumption. The simple intuition is that the law does not impact legal residents - both before and after the law is passed, legal residents can pay in-state tuition when attending an in-state public college or university. However, legal residents are impacted by other changes over time (e.g., economic conditions, tuition, attitudes toward education) that the affected group (undocumented immigrants) also experiences. Thus, we can estimate Equation 1 using a sample of legal residents and test if the estimate of $\beta$ is zero. This estimate of $\beta$ using legal residents is essentially an estimate of the differential trend, i.e., it is the difference in outcome that would exist between states that passed the laws earlier and other states even if there were no such laws at all. If this estimated differential trend is zero, then we have increased confidence that the parallel trend assumption holds. If it is not zero, we can still recover an estimate of the effect of the laws on undocumented immigrants by subtracting this differential trend away from the estimated $\beta$ using a sample of undocumented immigrants. More formally, estimate using a pooled sample of undocumented immigrants and legal residents:

(2) $y_{i s t j}=\alpha_{j}+\kappa$ INSTATE $_{s t} \times I(j=1)+\lambda$ INSTATE $_{s t}+\delta_{s j}+\gamma_{t j}+\mathbf{x}_{i s t, j} \rho_{j}+\varepsilon_{i s t j}$

for individual $i$ born in state $\underline{s}$ observed at time $t$ where $\mathrm{j}=1$ for an undocumented immigrant (i.e., the affected group, whose opportunities are changed by the laws) and $\mathrm{j}=0$ for legal residents (i.e., 
the comparison group, whose opportunities are unchanged). I(·) is the indicator function. Since all the parameters are allowed to vary by $\mathrm{j}, \lambda$ of Equation 2 is equal to the estimated $\beta$ from Equation 1 when using the comparison group individuals and $\kappa$ of Equation 2 is the difference between the estimated $\beta$ from Equation 1 when using the affected group individuals and $\lambda$. In other words, the estimated effect of the laws on undocumented immigrants is given by $\kappa$, which is the estimated $\beta$ using a sample of undocumented immigrants adjusted for the differential trend provided by the legal residents.

For $\kappa$ to be a convincing estimate of the effect of the laws permitting undocumented immigrants to pay in-state tuition, we must find a comparison group that adequately captures the differential trends in educational outcomes between states that passed the laws earlier and the other states. The comparison group we use is U.S.-born Hispanics. Since they are native-born American citizens, the laws do not change anything for them. At the same time, given the history of U.S. immigration and the relative recentness of immigration inflows from Latin America, a majority of U.S.-born children who are Hispanic are of the second generation (i.e., have at least one foreign-born parent). Thus, we can think about U.S.-born Hispanics as a group filled predominantly with children of immigrants. We might believe that U.S.-born children of immigrants and undocumented children living in a particular state experience many similar things, such as changes over time in the state's educational policies, economic conditions, population changes, and attitudes toward foreign-looking or foreign-sounding people. At the extreme, imagine a nuclear family containing undocumented parents, some undocumented children, and some U.S.-born children - then we might believe that all siblings experience similar things except that the undocumented siblings would benefit from the new laws. ${ }^{14}$ So it

\footnotetext{
${ }^{14}$ In our empirical analysis, we will not be able to use within family variation in legal status to identify the effect of
} 
seems that U.S.-born Hispanics could provide a credible estimate of differential trends in educational outcomes.

\section{Data}

To implement our identification strategy, we require a data set that is large enough to provide enough observations on a narrow subpopulation, foreign-born young adults who are likely to be undocumented. First, we focus on young adults because they are the primary candidates for attending college - although more and more people are taking college courses later in their lives, for the most part, college students come straight from high school or within a few years of leaving high school. For this paper, we will focus on individuals aged 18-24 with a high school degree when examining measures of college attendance. When we examine dropping out of high school as an outcome, we will examine people aged 16-17.

Second, although ideally we would like the affected group to be restricted to undocumented immigrants, the reality is that there are no nationally representative individuallevel data sets that indicate whether someone is an undocumented immigrant; obviously, legal status is sensitive information and difficult to elicit. In this study, we will define the affected group, which is known to contain much more undocumented immigrants than any of the comparison groups, as follows. The affected group contains Hispanic individuals who are foreign-born and not U.S. citizens, and arrived to the U.S. after 1981 and by age 14 (excluding Puerto Ricans). ${ }^{15}$ Our inability to separate the legal from undocumented immigrants does not

the laws. This is because there are no large data sets connecting adult siblings in the United States; for example, in the Census, we know family connections among individuals only if they reside in the same household. In this paper, we rely on a cross section of young adults, and use the U.S.-born Hispanics as a comparison group for the foreignborn children of immigrants, but the intuition of the within-family approach applies.

${ }^{15}$ A few clarifications: First, IRCA enabled immigrants who arrived in the United States by January 1, 1982, to become legal residents. It makes sense to ignore immigrants arriving in 1981 and earlier when seeking a group of people with high likelihood of being undocumented. Second, age at arrival to the United States is calculated as [current age - (survey year-year of immigration to the United States)]. Since the laws require attending high school 
invalidate our identification strategy, but it does reduce its power. Since there are legal residents mixed in with undocumented immigrants in this affected group, any detectable effect of the law on undocumented immigrants will be averaged over everyone in the affected group, which makes it harder to detect a statistically significant effect.

To implement our identification strategy, we use individual-level data from the American Community Survey (ACS). The ACS is modeled after the Census of Population and Housing long questionnaire, and it is an annual survey begun in 2000 to provide reliable intercensal data. We use the 2001-2005 ACS, and merge in the 20001 percent Census public use microdata sample (PUMS) files to get more "before" data. ${ }^{16}$ The 2005 ACS is the largest ACS sample to date - it is a 1-in-100 national random sample of the population - and older ACS samples are only one-half to one-third of that size.

We define the state law variable, INSTATE $E_{s t}$, as follows. Table 1 shows the first semester the law would have taken effect in each state passing the law. When a law takes effect in the fall semester of a particular year, we code $I N S T A T E_{s t}=1$ beginning the following year. For example, although the law took effect in fall 2001 for Texas, INSTATE $=0$ up through the 2001 survey year and INSTATE $=1$ beginning in 2002. California, the only state for which the policy did not begin in the fall (it began in spring 2002), has INSTATE $E_{s t}=1$ beginning 2002.

Because these laws were passed so recently and the latest ACS we use is from 2005, there will be few post-law years of data. ${ }^{17}$ In fact, the most recent passer, Nebraska, will not have any years of post-law data since fall 2006 is the first semester the law came into effect. This will

\footnotetext{
in the state for a certain number of years, it makes sense not to include immigrants who arrived at a later age - they simply would not meet the state qualifications for in-state tuition. Third, people born in Puerto Rico are U.S. citizens, so Puerto Ricans are not affected by the laws.

${ }^{16}$ We downloaded the data from the IPUMS website in October 2006 (Ruggles et al. 2004).

17 The 2006 ACS has become available since the working paper version of this chapter was issued in January 2007 , and adding these data to the analysis does not meaningfully change the results we report here.
} 
reduce the power, since there are few state-time cells where the law is effective. In the future, with more years of post-law data, we will be able to measure a wider range of outcomes (e.g., ultimate educational attainment, labor market outcomes) and be able to use more flexible functional forms that allow treatment effects to vary by state and years of exposure. For this paper, we will focus on attendance-related outcomes and a single average treatment effect.

Table 2 shows descriptive statistics for the ACS/Census sample for the educational outcomes we will be analyzing below. In the affected group (i.e., Hispanic non-U.S.-citizen immigrants), 32 percent of 18-24 year-olds with a high school degree are currently attending college, and 11 percent of 16-17 year-olds have dropped out of high school. Educational outcomes are worse for men than women, and for Mexicans than Hispanics overall (Mexicans make up about 60 percent of the affected group). Additionally, the affected group is doing worse than the U.S.-born comparison group (i.e., U.S.-born Hispanics: Columns 7-12), which is in turn doing worse than U.S.-born non-Hispanic whites. ${ }^{18}$ Finally, the affected group has a lower propensity to attend private colleges than either the U.S.-born comparison group or the U.S.-born non-Hispanic whites.

Of course the identification strategies described by Equations 1 and 2 do not involve just taking differences between groups to obtain effects of the law, and instead rely on differences in the evolution of educational outcomes over time following the passage of the law between states with the law and states without the law. Thus, it is useful to graph educational attainment measures by year for states with the law and states without the law. These graphs of the raw data are useful for discerning pre-existing trends in the measures and see trend breaks, if any, starting

\footnotetext{
${ }^{18}$ We will not use U.S.-born non-Hispanic whites in our regression analysis below. We present their descriptive statistics here only to provide a reference point.
} 
from the passage of the laws. ${ }^{19}$ Panel A of Figure 1 shows the graph of college attendance among 18-24 year-olds with a high school degree for the affected group. The survey years 2000 and 2001 are both "before" years for every state. Then in 2002, the law comes into effect in Texas and California.

It would be incorrect to attribute all differences between 2001 and 2002 in Texas and California to the laws permitting undocumented students to pay in-state tuition, however, since there appear to be secular changes over time (as indicated by the college attendance in states without the law yet in 2002 - the later-law states and never-law states on the graph experiencing changes between 2001 and 2002). In Equation 1, we use states that passed the laws later or never passed the law to control for secular time changes. This may not be wholly satisfactory since Panel A of Figure 1 suggests that prior to any state implementing the law, the trend in college attendance does not appear similar between the earlier-law states and other states. It is therefore useful to use a comparison group of people whose opportunities are not impacted by the laws to correct for the differential trend, which is what Equation 2 does. Our comparison group for obtaining the differential trend will be U.S.-born Hispanics; Panel B of Figure 1 graphs college attendance among 18-24 year-olds with a high school degree for this group.

On a separate note, we can obtain consistent estimates of the parameters in Equations 1 and 2 via ordinary least squares (OLS) only if all the right-hand side variables are exogenous. Thus, it is important to consider whether $I N S T A T E_{s t}$ can plausibly be viewed as exogenous. Our reading of the circumstances surrounding the passage of these laws is that the laws were passed out of fairness considerations - it was believed that children who grew up in the state and

\footnotetext{
${ }^{19}$ Unfortunately, given that the ACS in 2001-2004 are only one-third to one-half of a percent of the U.S. population, and that some states have little immigration, some state-year cells will have few observations for the affected group, leading to a noisy series. It is preferable to pool data to gain efficiency, as we do in the regression analysis below.
} 
performed well in K-12 deserved to have the same opportunity to attend college as their legally resident classmates, and should not punished for the fact that their parents entered and stayed in the United States illegally. These laws were not a response to perceptions that educational outcomes for undocumented students were getting worse or better. Thus, it seems reasonable to consider the dummy for having the law as exogenous to educational outcomes. However, it could be a concern that states that passed these laws are also passing other laws to help undocumented immigrants or improving their attitudes about undocumented immigrants over time. More specifically, although state fixed effects allow states to differ in how they treat undocumented immigrants, there remains room for bias caused by time-varying state attributes (e.g., other policies, changes in unmeasured state attributes over time). Using U.S.-born Hispanics as a comparison group helps mitigate bias associated with state-specific changes in policies and attitudes toward immigrants since many of them are children of immigrants. ${ }^{20}$

\section{Results}

\section{A. Effect on College Attendance}

First, we examine the effect of the laws on the probability of attending college among people who are currently aged 18-24 and possess a high school degree. Using ACS/Census data, we are able to distinguish between college attendance in public and private institutions. ${ }^{21}$ In Table 3, we present the results of estimating Equation 1 using individuals in the affected group.

The general result is that there are no statistically significant effects at conventional

\footnotetext{
${ }^{20}$ Moreover, we considered several alternative comparison groups: (1) Asian immigrants; (2) non-Hispanic and nonAsian immigrants; and (3) Hispanic immigrants who are naturalized U.S. citizens. These groups, as immigrants themselves, might better control for state-specific changes in policies and attitudes toward immigrants. Since the results using these alternative comparison groups are qualitatively similar to those using the U.S.-born Hispanic comparison group, we do not report them.

${ }^{21}$ Unfortunately, the ACS/Census data do not distinguish between four-year and two-year institutions. Future analysis using data from the Current Population Survey can examine whether the laws impacted attendance at fouryear and two-year institutions differently.
} 
levels of significance (e.g., 5 percent or better). In Panel A, when a sample pooling men and women is used, we detect no effect for either Hispanics overall or Mexicans only, although it can be said that the point estimates for 22-24 year-olds tend to be positive and of greater magnitude than for the 18-21 year-olds. In Panel B, restricting focus to men, we notice larger positive point estimates for 22-24 year-olds compared to the pooled sample, which lead to more positive point estimates for men overall that are sometimes significant at the 10 percent level of significance. The positive effects come largely from the increased probability of attending public colleges the point estimates for attending private colleges is close to zero. These findings are consistent with the laws having an impact since the laws would operate through attendance at state institutions (the laws do not change prices for anyone at private institutions).

In Panel C, restricting the focus to women, most of the point estimates are actually negative. The only significant effects for women are for the private college attendance of Mexican women aged 22-24 - and they are positive! The results for Mexican women are puzzling, since we would not have expected negative effects of the laws on public college attendance but positive effects on private college attendance. To summarize the findings of Table 3 , there is a suggestion of a benefit of the laws on older Mexican men, although differential trends appear to be an important issue that must be considered before drawing conclusions.

To explore the problem of differential trends, we estimate Equation 1 for the U.S.-born comparison group. Since the laws do not change anything for the U.S.-born comparison group, the estimated $\beta$ can be thought of as an estimate of the differential trend prevailing between states with the law and states without the law. The results are displayed in Table 4, and are generally statistically insignificant, which is evidence in support of the parallel trend assumption. Interestingly, in Panel B, the point estimates for public college attendance of men are generally 
negative, which means that without the law, Mexicans' college attendance would have fallen in states with the law relative to states without the law; this means the corrected estimates will reveal an even larger benefit of the laws on Mexican men than is suggested in Table 3 (which shows uncorrected estimated).

In Table 5, we present estimates of the effect of the laws on the affected group that are adjusted for differential trends. Specifically, we subtract Table 4 estimates (which are estimates of the differential trends using the U.S.-born comparison group) from the Table 3 estimates. ${ }^{22}$ For example, in Table 3, Panel B, the coefficient is 0.0603 for Hispanic men aged 18-24 in the affected group. In Table 4, Panel B, the coefficient is -0.0206 for Hispanic men aged 18-24 in the comparison group. In Table 5, Panel B, the coefficient is 0.0809 [=.0603-(-.0206)] for Hispanic men aged 18-24. The estimated effect of the laws on males in the affected group, adjusted for differential effects using U.S-born Hispanic males, is 8.09 percent. That is, the laws raised college attendance 8.09 percent among Hispanic men aged 18-24 who are foreign-born and not U.S. citizens.

Because the Table 4 results were typically around zero, and for males of opposite sign, all the effects found in Table 3 are carried through to Table 5. In particular, the overall small and near-zero effects found for the pooled sample of men and women mask positive effects for men and negative effects for women. The positive effect for men derives from the significantly higher likelihood that older (aged 22-24) Mexican men are attending public colleges. Puzzlingly, older Mexican women, though no more likely to attend public colleges (if one takes the point estimates literally, they are actually less likely), are more likely to attend private colleges.

To summarize the results of Tables 3-5, we find some evidence suggestive of a positive

\footnotetext{
${ }^{22}$ In practice, we obtain the effects shown in Table 5 by estimating Equation 2 by OLS. Estimating in regression form makes it easier to get the standard errors associated with the effects.
} 
effect of the laws on the college attendance of Mexican men, but in general estimated effects of the laws are not significantly different from zero. In an earlier section, we provide some reasons for the insignificant results. Here, we discuss the effect on Mexican men in more detail.

The point estimate of the effect on the college attendance of Mexican men is large - in Table 5, the effect of the laws on the probability that Mexican men aged 22-24 who are foreignborn and not U.S. citizens are currently attending college is 15 percent, which is more than half of the mean college attendance rate for Mexican men - although quite imprecise (the 95 percent confidence interval is 0.6 percent to 29.7 percent). ${ }^{23}$ In contrast, the point estimates of the effect on Mexican women and younger Mexican men are not only insignificant but also much less than 15 percent. Why should the effect be larger for men than women, and larger for older men (aged 22-24) than younger men (aged 18-21)?

At first blush, it is surprising that men alone benefit since females tend to do better than males in K-12, which puts females in a better position to apply successfully to college and succeed in college. Dynarski (2005) found that Hispanic and nonwhite women experienced the largest gains in college attendance and degree completion among all race/ethnicity-sex groups as a result of the Arkansas and Georgia merit aid programs. Why would we find the opposite here? First, it is important to point out that these laws allowing undocumented students to pay in-state tuition do not provide merit-based benefits. The law does not only benefit undocumented immigrants with good grades who are eligible to pay in-state tuition rates; all undocumented immigrants who attended high school and received a high school degree in that state can benefit.

\footnotetext{
${ }^{23}$ So far, we have estimated the effect of the law on the affected group. Of course the affected group contains both undocumented immigrants and legal immigrants. To get the effect of the law on the undocumented immigrants, we would have to divide the estimated effect on the affected group by the fraction of the affected group that is undocumented. We do not know the exact fraction, but based on the fact that 52 percent of the stock of Mexican immigrants is undocumented and that new immigrant inflows from Mexico are increasingly illegal over time, then we would guess that fraction is in excess of 50 percent. This means that to obtain an upper bound on the effect of treatment on the undocumented immigrants, we can multiply the reported estimated effects on the affected group by two (the reciprocal of .5 is 2 ).
} 
Second, although it is true that women, including Mexican women in the affected group, are more likely to obtain a high school degree, the fact is that our analysis is conditional on having a high school degree. Only people with high school degrees are eligible to benefit from the law, hence we have focused on them in our analysis of high school attendance. It is possible that males who graduate from high school have different underlying ability than females who graduate from high school, since the former drop out of high school at much higher rates. If we assumed that men and women each had the same ability distribution and that people of lower ability are more likely to drop out, then the higher high school dropout rate for males would suggest that the smaller pool of male high school graduates have higher average ability. It is plausible that the law impacts people of higher ability more, which leads to a larger estimated benefit of the laws for men than women. If we had not conditioned on having a high school degree, then results by sex would likely be different than what we found here. ${ }^{24}$

It may also be surprising that older Mexican males benefit more than younger Mexican males (also, the point estimates for the effect of the laws on public college attendance are higher for older Hispanic females than for younger Hispanic females, although none of these point estimates are significant). Why should the effect of the laws differ by age? Seftor and Turner $(2002,349)$ estimate that availability of federal financial aid increases the college enrollment of older students: "The behavioral effects for the traditional college-aged students associated with changes in the availability of Pell funding are modest, but the responsiveness among older students is marked." The main reason offered for the differential effects by age is that older students may face greater credit constraints than younger students. Older students may be less able to get funding from parents, as they are less likely to be living with the parents - and from banks, as they are attending community colleges instead of traditional four-year colleges. In the

\footnotetext{
${ }^{24}$ Future analysis will model the differential selectivity of men and women into the sample.
} 
case of undocumented immigrants, while greater credit constraints may well be present for older youths, we believe there is another important reason for the greater effects on older youths. ${ }^{25}$ Undocumented immigrants may wish to take advantage of the law, but they have a competing desire to conceal the undocumented status of their family. Given the United States' unstable attitudes toward immigrants, undocumented immigrants face a constant threat of deportation and may be reluctant to have an official government record (e.g., student record at a public college) that indicates undocumented status and contains family information. Compared to the 18-21 year-olds, 22-24 year-olds are more likely to be living on their own. People who live on their own cannot easily be linked to their family. Hence, older Mexicans are more likely than younger Mexicans to take advantage of laws permitting undocumented immigrants to pay in-state tuition.

\section{B. Effect on Dropping Out of High School}

It could be that the law, by increasing student expectations of attending college, raises high school completion for younger cohorts. In this subsection, we examine the effect of the laws on the dropping out of high school among people who are currently aged 16-17. We define dropping out of high school as not having a high school degree and not currently attending school. Note that many people who will eventually drop out have not yet done so by age 17 , thus by focusing on 16-17 year-olds we are capturing early dropout behavior.

Table 6 shows the estimated effects of the tuition laws on dropping out of high school. The general conclusion from this table is that neither the unadjusted estimates (obtained by estimating Equation 1 using the affected group) nor the adjusted estimates (which were obtained

\footnotetext{
${ }^{25}$ It is possible to imagine older students being less, not more, credit constrained. Older youths would have worked and saved money for longer, which enables them to attend college if they wished (so when the passage of the laws presents the opportunity to attend college, older people can respond quickly whereas younger people must wait and save). Older students being less credit constrained may be the more likely situation for undocumented immigrants since they come from very poor families that cannot spare enough money for college even if the parents were supportive of college.
} 
by estimating Equation 2 using the affected group combined with the U.S.-born Hispanic comparison group) suggest any significant effects of the laws on dropout behavior. However, it is true that the point estimates are generally negative, consistent with a decline in dropping out as a consequence of the laws. If indeed high school dropout rates are declining in response to the laws, we might expect an increase in college attendance in the future as these 16-17 year-olds come of age and wish to attend college.

\section{Conclusion}

The staggered adoption of state laws permitting undocumented students to pay in-state tuition provides a natural experiment for evaluating the effects of such laws. We found some evidence suggestive of a positive effect of the laws on the public college attendance of older Mexican men. For younger, female, and non-Mexican members of the affected group, however, the effects of the laws on college attendance were typically not significantly different from zero. Additionally, there were no significant effects of the laws on high school dropout behavior among 16-17 year olds. Thus, our main finding is that estimated effects tend not to be significant. At this point, we do not wish to put too much emphasis on the significant effects for older Mexican men. On the one hand, they are sensitive to the specific comparison group used to correct for differential trends in college attendance. On the other hand, given the sheer number of regressions we have estimated, it is to be expected that a small handful of these regressions will show significant effects. In future work, we will further scrutinize the positive effect on the college attendance of older Mexican men.

The most obvious interpretation of this finding - of no significant effects - is that the laws truly do not affect the educational outcomes of undocumented students. This could be for a number of reasons. First, although the laws made attending college cheaper, the in-state tuition 
rates may still be prohibitively expensive for undocumented students. Undocumented students do not qualify for federal financial aid, the chief source of financial aid for college students. Second, the laws do not change the legal status of undocumented immigrants, and due to IRCA employer sanctions, undocumented immigrants will continue be unable to access good jobs even with a college degree. These first two reasons suggest that without corresponding changes in the federal government's treatment of undocumented students (e.g., setting qualifications for federal financial aid or creating a legalization process) it may be unreasonable to expect significant increases in educational attainment due to these laws.

A third reason that there might truly be no effect is that too little time has elapsed since the laws were passed. The most recent data we were able to obtain are from 2005, but the earliest any state implemented the law was fall 2001 - at the time of this writing, a maximum of five years and a median of three years have elapsed since the adoption of the laws. Because of the newness of the law, perhaps undocumented immigrants may not even be aware of its existence. Or, perhaps they are aware, but have not accumulated the credentials (e.g., a high school degree, rigorous high school classes) to place themselves in a position to take advantage of the law. This third reason suggests that the short-run effect of the law may well differ from the longer-run effect. As information spreads about these laws, the estimated effect might change. ${ }^{26}$ Also, younger cohorts would have had time to accumulate the right credentials to attend college, and the estimated effect on them could well differ from the effect on people who made schooling choices not expecting to attend college but then are unexpectedly given the opportunity to do so.

Another interpretation of the finding is that the laws do affect the educational outcomes

\footnotetext{
${ }^{26}$ Education policymakers should undertake actions to spread the word about these laws to undocumented students, guidance counselors in junior high and high schools serving undocumented students, and leaders in communities with undocumented students. This would remove the possibility that the estimated results relate to a failure to provide information about the law to the intended beneficiaries, and it would improve our confidence that the estimated results truly relate to the impact of the law itself.
} 
of undocumented students, but our statistical tests lack the power to detect these effects. There were so few observations exposed to the law - given the recent passage of these laws, only a few state-time cells are "treated" to the law - that we have sufficient power only to detect relatively large effects on educational outcomes. The inability to distinguish undocumented immigrants from other non-citizen immigrants exacerbates the problem, since it means that among the observations coded as exposed to the law, only a subset would actually have experienced a change in opportunities (e.g., legal immigrants lumped into the treated group would not have experienced any change in opportunities). Thus, we cannot rule out that modest short-run effects existed, but statistically we cannot distinguish that from a zero effect. We have, however, ruled out large short-run effects. $^{27}$

In the future, it will be useful to assess the longer-run effects of the laws permitting undocumented students to pay in-state tuition. There is good reason to believe the longer-run effects differ from the short-run effects. Using the same empirical methodology used in this paper, we would be able to look at outcomes related to college persistence (e.g., completion of an associate's or bachelor's degree) after more time passes. ${ }^{28}$ Additionally, with more data, we would be able to test whether effects vary by state; it is conceivable that states differ in how effectively they have advertised the law, which may have implications for the estimated effect on undocumented immigrants.

\footnotetext{
${ }^{27}$ Given the standard errors, an effect in excess of 6 percent to 10 percent (depending on the subsample) would be detectable as a significant effect. For older Mexican men, we did detect a large short-run effect on college attendance- - the point estimate was 15 percent according to Table 5. For all other groups and outcomes, we can rule out effects larger than 6 percent to 10 percent.

${ }^{28}$ Dynarski (2005) reports: "In the 2000 Census, just 57 percent of those age 22 to 34 with any college experience had completed an associate's or bachelor's degree. Thirteen percent had not completed even a year" (p. 1). The Hoxby (2004) edited volume emphasizes the distinction between college attendance and college persistence. This paper has focused on college attendance, and given the low proportion of Hispanic immigrants who have attempted college, access to college may be a major problem for this subpopulation, and it is of policy interest to raise college attendance.
} 


\section{References}

Capps, Randy, Michael Fix and Jane Reardon-Anderson. 2003. "Children of Immigrants Show Slight Reductions in Poverty, Hardship." Snapshots of American Families III, No. 13, Washington, D.C.: Urban Institute.

Card, David, John DiNardo, John and Eugena Estes. 2000. “The More Things Change: Immigrants and the Children of Immigrants in the 1940s, the 1970s, and the 1990s." In George J. Borjas (Ed.) Issues in the Economics of Immigration, Chicago: University of Chicago Press, 227-270.

Dynarski, Susan M. 2000. "Hope for Whom? Financial Aid for the Middle Class and Its Impact on College Attendance.” National Tax Journal 53:3, 629-661.

Dynarski, Susan M. 2003. "Does Aid Matter? Measuring the Effect of Student Aid on College Attendance and Completion.” American Economic Review 93:1, 279-288.

Dynarski, Susan M. 2005. "Building the Stock of College-Educated Labor.” Harvard University Kennedy School of Government Mimeo (November 2005).

Education Commission of the States. 2006. "Recent State Policies/Activities, Tuition and FeesIn-state Tuition for Undocumented Immigrants." Education Commission of the States State Policy Database. (http://www.ecs.org/ecs/ecscat.nsf/WebTopicView?OpenView\&count=300\&RestrictToCategory=Tuition/Fees--InState+Tuition+for+Undocumented+Immigrants)

Grogger, Jeffrey and Stephen J. Trejo. 2002. Falling Behind or Moving Up? The Intergenerational Progress of Mexican Americans, San Francisco: Public Policy Institute 
of California.

Hansen, W. Lee. 1983. “The Impact of Student Financial Aid on Access.” In Froomkin, Joseph, (ed.) The Crisis in Higher Education. New York: Academy of Political Science, 84-96.

Hoxby, Caroline M. (Ed.). 2004. College Choices: The Economics of Where to Go, When to Go, and How to Pay for It. Chicago: University of Chicago Press.

Institute of Public and International Affairs. 2006. Mexico and Utah: The Complex Relationship. Salt Lake City: University of Utah. (http://www.ipia.utah.edu/utah_mexico/full_text.pdf).

Jordan, Miriam. 2005. “Illegal Immigrants' New Lament: Have Degree, No Job.” Wall Street Journal. Section B, pp. 1 and 7, April 26, 2005.

Kane, Thomas J. 1994. "College Entry by Blacks since 1970: The Role of College Costs, Family Background and the Returns to Education.” Journal of Political Economy 102:5, 878-911.

Kane, Thomas J. 1995. "Rising Public College Tuition and College Entry: How Well Do Public Subsidies Promote Access to College.” NBER Working Paper 5164.

Kane, Thomas J. 2003. "A Quasi-Experimental Estimate of the Impact of Financial Aid on College-Going,” NBER Working Paper 9703.

Kaushal, Neeraj. 2008. "In-State Tuition for the Undocumented: Education Effects on Mexican Young Adults.” Journal of Policy Analysis and Management 27:4, 771-792.

Kossoudji, Sherrie A. and Deborah A. Cobb-Clark. 2002. "Coming out of the Shadows: Learning about Legal Status and Wages from the Legalized Population,” Journal of Labor Economics 20:3, 598-628.

Krueger, Carl. 2006. "In-state Tuition for Undocumented Immigrants.” Education Commission 
of the States StateNotes: Tuition and Fees (August 2006)

(http://www.ecs.org/clearinghouse/61/00/6100.htm)

Lewis, Raphael. 2005. “In-State Tuition Not a Draw for Many Immigrants.” Boston Globe. November 9, 2005.

Martin, Jack. 2005. "Breaking the Piggy Bank: How Illegal Immigration is Sending Schools into the Red.” Federation for American Immigration Reform Report (June 2005) (http://www.fairus.org/site/PageServer?pagename=research_researchf6ad).

Passel, Jeffrey S. 2005. "Unauthorized Migrants: Numbers and Characteristics.” Washington, D.C.: Pew Hispanic Center.

Ruggles, Steven, Matthew Sobek, Trent Alexander, Catherine A. Fitch, Ronald Goeken, Patricia Kelly Hall, Miriam King, and Chad Ronnander. 2004. Integrated Public Use Microdata Series: Version 3.0 [Machine-readable database]. Minneapolis, MN: Minnesota Population Center [producer and distributor] (http://www.ipums.org).

Seftor, Neil and Sarah Turner. 2003. "Back to School: Federal Student Aid Policy and Adult College Enrollment.” Journal of Human Resources 37:2, 591-617.

Smith, James P. 2003. “Assimilation Across the Latino Generations.” American Economic Review Papers and Proceedings 93:2, 315-325.

Smith, James P. 2006. "Immigrants and the Labor Market.” Journal of Labor Economics 24:2, 203-233.

U.S. Department of Education, National Center for Education Statistics (NCES). 2003. Integrated Postsecondary Education Data System (IPEDS), "IPEDS State Tables 2003" (http://nces.ed.gov/das/library/tables_listings/state2003_price.asp). 
Figure 1. College Attendance Among 18-24 Year Olds, 2000-2005

Panel A. Hispanic Non-U.S.-Citizen Immigrants (Affected Group)

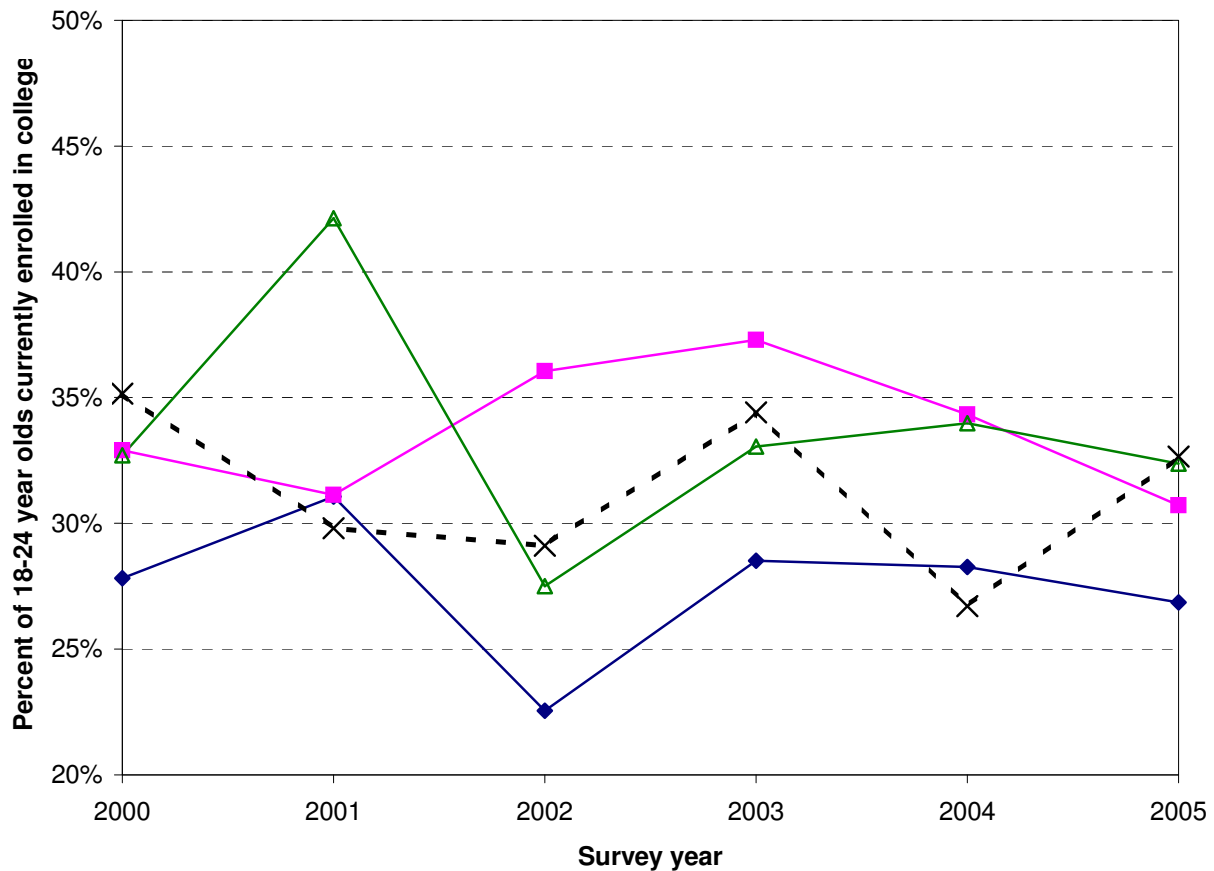

Panel B. U.S.-Born Hispanics (Comparison Group)

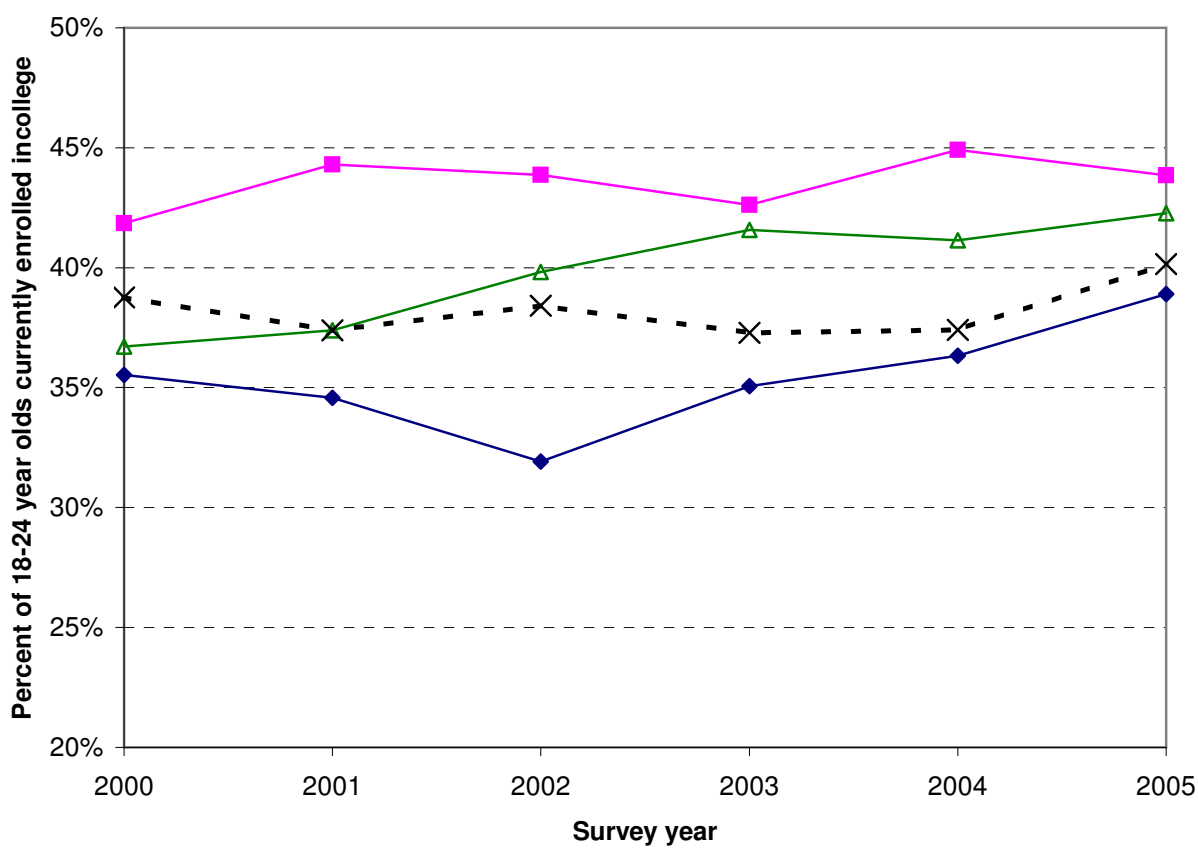

Texas $\longrightarrow$ California $\triangle \Delta$ Later-law states $-\not x-\cdot$ Never-law states

Notes: The sample consists of individuals from the 2000 Census 1\% PUMS files and the 2001-2005 American Community Survey who are currently age 18-24 and Hispanic (excluding Puerto Ricans) with additional restrictions as follows. In Panel A, people are foreign-born and not U.S. citizens, and arrived to the U.S. after 1981 and by age 14. In Panel B, people are U.S.-born. Means are weighted by IPUMS weights. The laws would have become effective in the 2002 survey year for Texas and California. The laws would have become effective after 2002 for the "Later-law states", UT, NY, WA, OK, IL, KS, NM and NE. The states that do not have the law as of August 2006 are in the "Never-law states" category. 
Table 1. State Laws Allowing Undocumented Students to Pay In-State Tuition

\begin{tabular}{llcc}
\hline State & Name of law & Date law was passed & First semester law was effective \\
\hline Texas & H.B. 1403 & May 2001 & Fall 2001 \\
California & A.B. 540 & April 2001 & Spring 2002 \\
Utah & H.B. 331 & March 2002 & Fall 2002 \\
New York & S.B. 7784 & August 2002 & Fall 2002 \\
Washington & H.B. 1079 & May 2003 & Fall 2003 \\
Oklahoma & S.B. 596 5903 & Fall 2003 \\
Illinois & H.B. 60 & May 2003 & Fall 2003 \\
Kansas & H.B. 2145 & May 2003 & Fall 2004 \\
New Mexico & S.B. 582 & May 2004 & Fall 2005 \\
Nebraska & L.B. 239 & April 2005 & Fall 2006 \\
\hline \hline
\end{tabular}

Source: Education Commission of the States (2006). 
Table 2. Descriptive Statistics

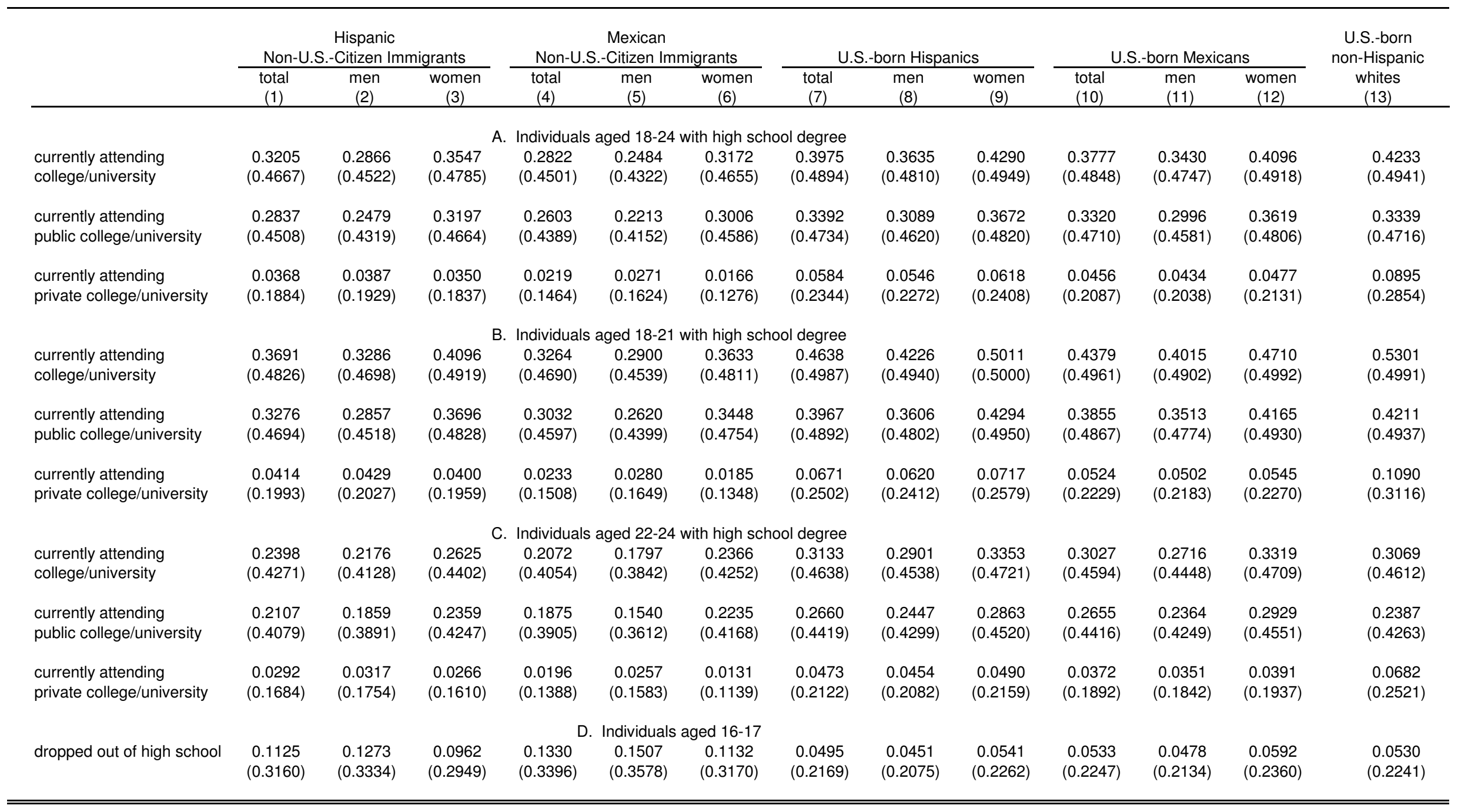

Notes: The sample consists of individuals from the 2000 Census 1\% PUMS files and the 2001-2005 American Community Survey with additional restrictions as follows. In Columns 1-6, people are foreign-born and not U.S. citizens, arrived to the U.S. after 1981 and by age 14 and Hispanic (excluding Puerto Ricans). In Columns 7-12, people are U.S.-born and Hispanic (excluding Puerto Ricans). In Column 13, people are U.S.-born, white and non-Hispanic. Observations with allocated age, birthplace, year of immigration, school attendance were dropped. Currently attending college variables are constructed based on the IPUMS variables school attendance (school), grade attending (gradeatt) and school type (schtype), with observations with allocated values for school and schtype dropped. Dropped out of high school variable is constructed based on the IPUMS variables educational attainment (educ99) and school attendance (school), with observations with allocated values for educ99 and school dropped. A person is coded as a high school dropout if he/she has completed fewer than 12 years of schooling and is not currently attending school. 
Table 3. Effect of State Laws on College Attendance of Non-U.S.-Citizen Immigrants

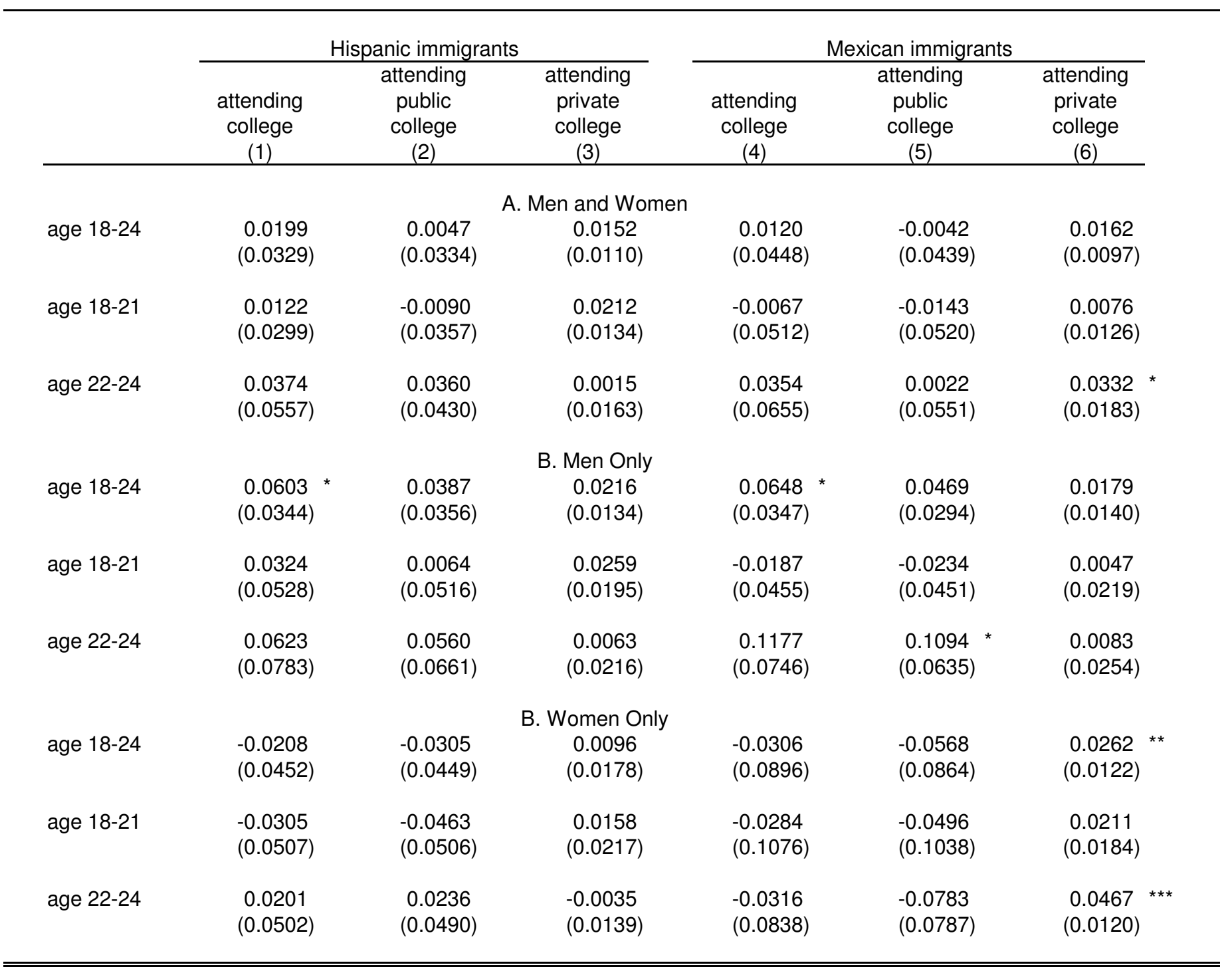

Notes: The sample consists of individuals from the 2000 Census 1\% PUMS files and the 2001-2005 American Community Survey who are currently age 18-24, foreign-born and not U.S. citizens, arrived to the U.S. after 1981 and by age 14, Hispanic and have a high school degree. Each cell is from a separate regression that is weighted by IPUMS weights and contains dummies for the survey year, state of residence, age, age at arrival, race and sex; Columns 1-3 additionally control for Hispanic origin dummies (Mexican, Cuban and Other). Robust standard errors from clustering by state of residence are shown in parentheses. Asterisks denote significance levels $\left({ }^{*}=.10,{ }^{* *}=.05,{ }^{* * *}=.01\right)$. For Hispanic immigrants analysis in Columns 1-3, there are 7152 observations (3652 women and 3500 men). For Mexican immigrants analysis in Columns 4-6, there are 4643 observations ( 2340 women and 2303 men). 
Table 4. Effect of State Laws on College Attendance of U.S.-Born Comparison Group

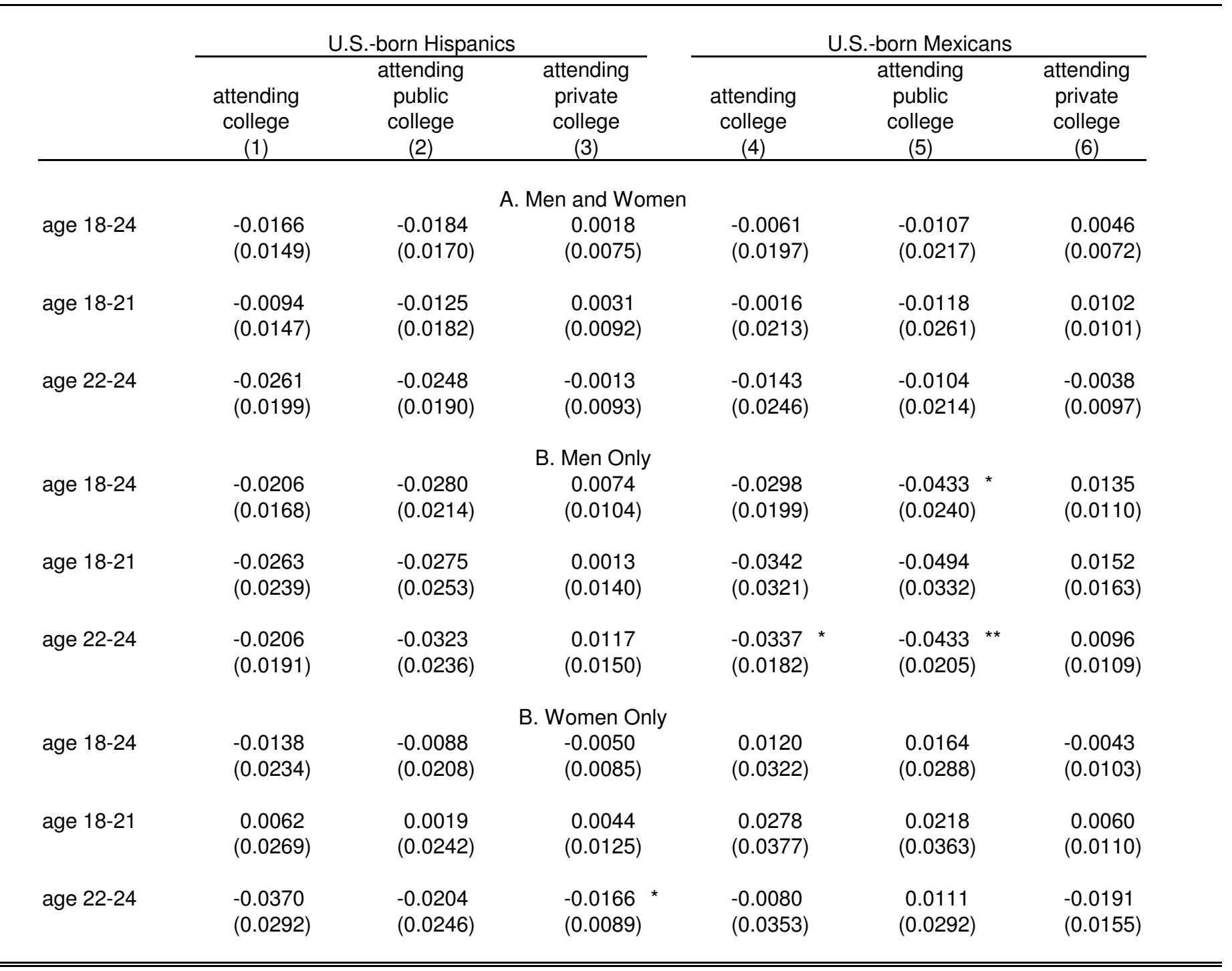

Notes: The sample consists of individuals from the 2000 Census 1\% PUMS files and the 2001-2005 American Community Survey who are currently age 18-24, U.S.-born, Hispanic (excluding Puerto Ricans) and have a high school degree. Each cell is from a separate regression that is weighted by IPUMS weights and contains dummies for the survey year, state of residence, age, age at arrival, race and sex; Columns 1-3 additionally control for Hispanic origin dummies (Mexican, Cuban and Other). Robust standard errors from clustering by state of residence are shown in parentheses. Asterisks denote significance levels $\left({ }^{*}=.10,{ }^{* *}=.05,{ }^{* * *}=.01\right)$. For Hispanic immigrants analysis in Columns $1-3$, there are 41418 observations (22107 women and 19311 men). For Mexican immigrants analysis in Columns 4-6, there are 29648 observations (15726 women and 13922 men). 


\section{Table 5. Effect of State Laws on College Attendance of Non-U.S.-Citizen Immigrants, Adjusted for Differential Trend using the U.S.-Born Comparison Group}

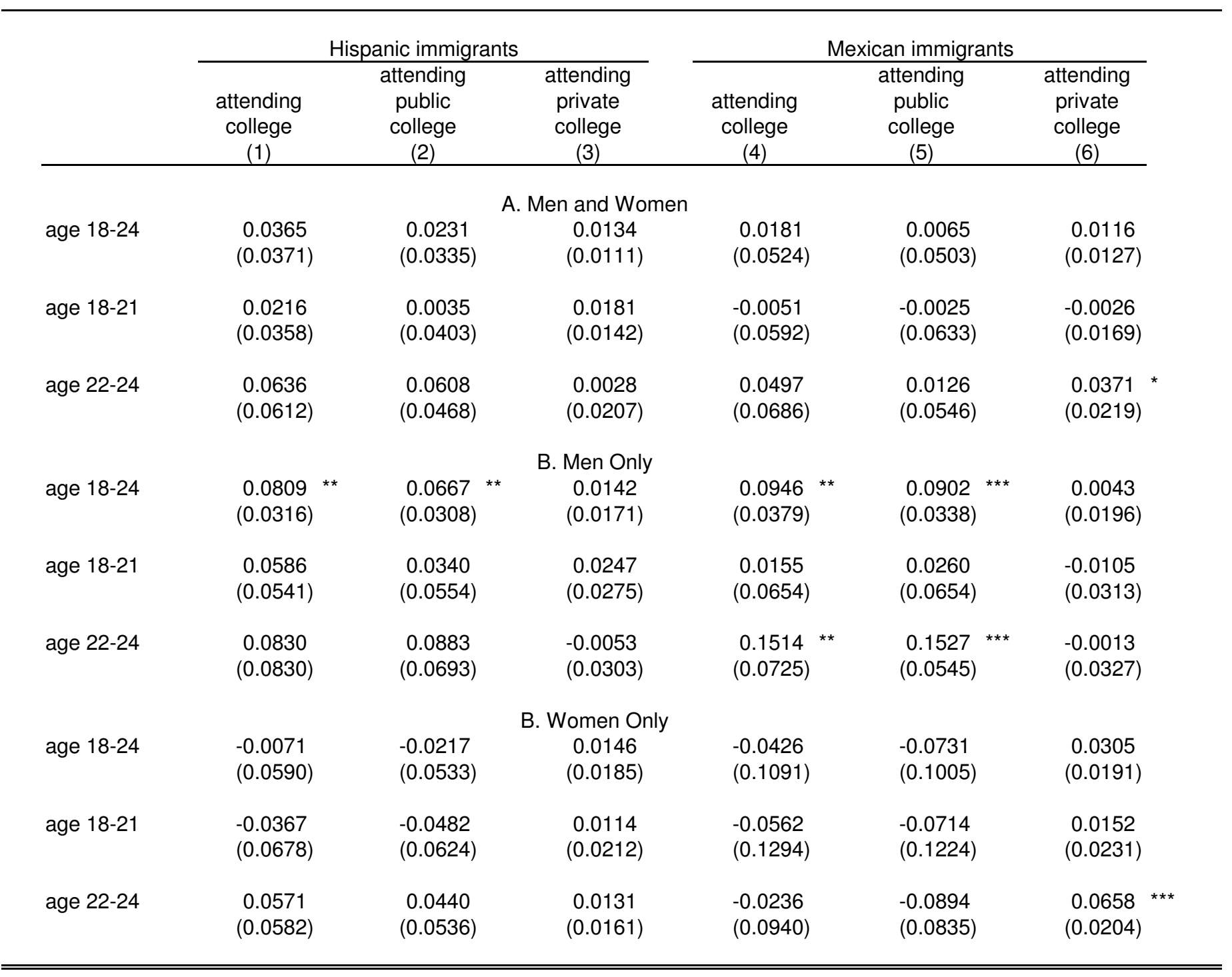

Notes: This table reports the difference between the effect on non-U.S.-citizen immigrants reported in Table 3 and the effect on the U.S.-born comparison group reported in Table 4 for a given outcome, age and Hispanic/Mexican group. In practice, these adjusted effects were obtained from regressions pooling the affected (immigrant) and comparison (U.S.-born) groups and allowing all coefficients to differ between the two groups; the reported coefficient is the coefficient for the interaction between being in the affected group and the "INSTATE" variable. 
Table 6. Effect of State Laws on Dropping Out of High School for 16-17 Year Olds

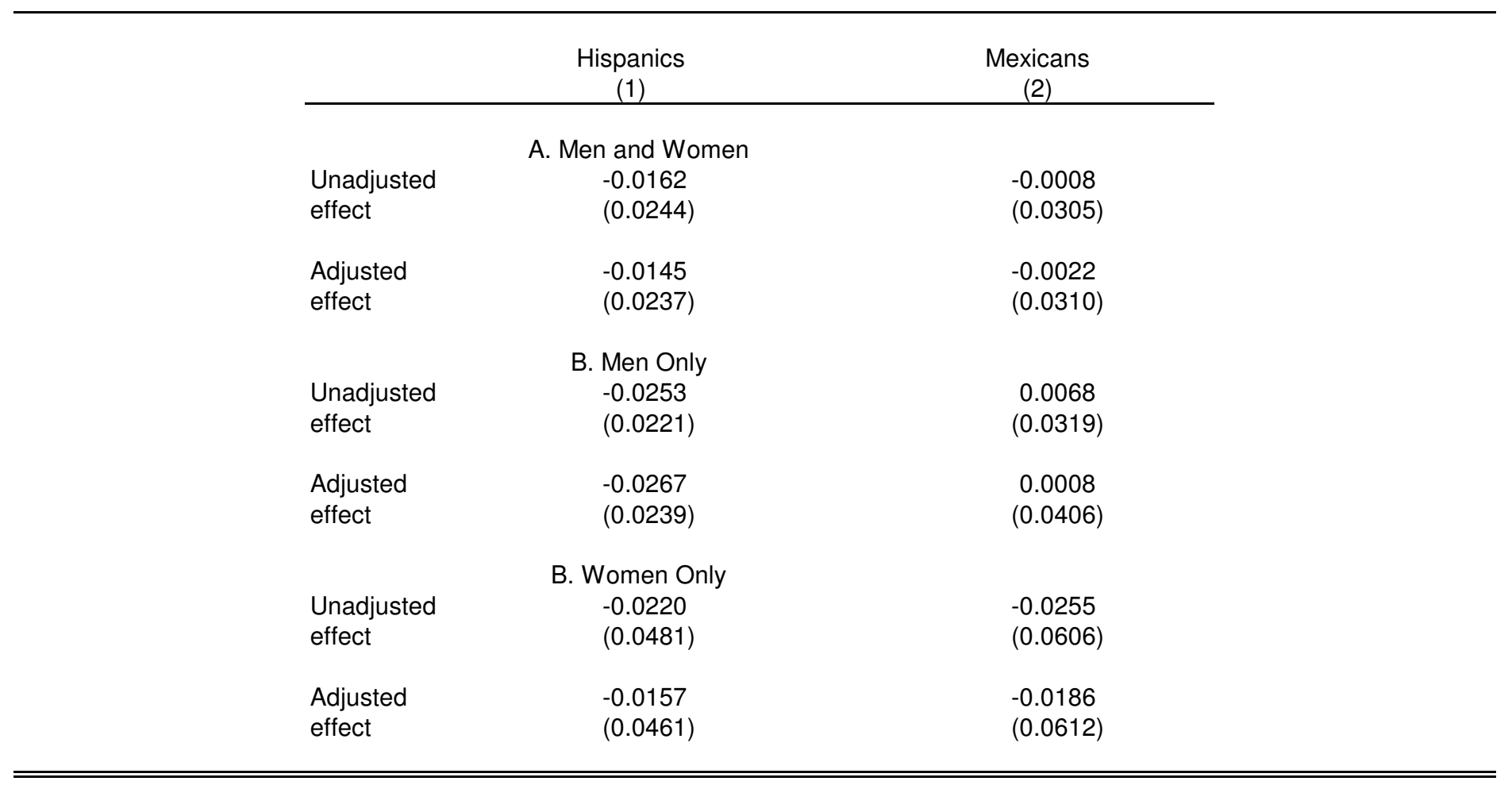

Notes: The sample consists of individuals from the 2000 Census 1\% PUMS files and the 2001-2005 American Community Survey who are currently age 16-17 with additional restrictions as follows. The affected group is Hispanic, foreign-born and not U.S. citizens, and arrived to the U.S. after 1981 and by age 14 (Column 2 is restricted to Mexicans). The comparison group is born in the U.S. and Hispanic (excluding Puerto Ricans; only Mexicans are used for comparison in Column 2). The "unadjusted effect" is the coefficient for "INSTATE" from Equation 1 estimated using data on the affected group. The "adjusted effect" is the coefficient for interaction between being in the affected group and "INSTATE" from Equation 2 using data on the affected group and comparison group. Robust standard errors from clustering by state of residence are shown in parentheses. Asterisks denote significance levels $\left({ }^{*}=.10,{ }^{* *}=.05,{ }^{* \star *}=.01\right)$. 